\title{
Pengaruh Salinitas terhadap Pertumbuhan dan Aktivitas Antioksidan Dunaliella salina (Chlorophyceae: Dunaliellaceae)
}

\author{
Intan Budi Setiasih*, Agus Sabdono, Rini Pramesti \\ Departemen IImu Kelautan, Fakultas Perikanan dan IImu Kelautan, Universitas Diponegoro \\ JI. Prof.H.Soedarto S.H, Tembalang,Semarang, Jawa Tengah 50275 Indonesia \\ ${ }^{*}$ Corresponding author, e-mail : intanbsraharjo.id@gmail.com
}

\begin{abstract}
ABSTRAK: Dunaliella salina merupakan salah satu jenis mikroalgae hijau yang mengandung berbagai senyawa bioaktif termasuk senyawa antioksidan untuk melawan radikal bebas. Pertumbuhan mikroalgae dipengaruhi oleh lingkungan salah satunya adalah salinitas. Penelitian ini bertujuan mengetahui salinitas optimal untuk pertumbuhan dan aktivitas antioksidan $D$. salina berdasarkan nilai persen inhibisi. Penelitian ini dilaksanakan di Laboratorium Terpadu dan Laboratorium Biologi Fakultas Perikanan dan Ilmu Kelautan, Universitas Diponegoro, Semarang pada bulan Mei - Juli 2018. Metode penelitian yang digunakan adalah eksperimental laboratoris. $D$. salina dikultur pada lima salinitas yang berbeda yaitu 20, 25, 30, 35 dan 40 ppt. Pengamatan dilakukan selama $7 \times 24$ jam, dipanen dan diekstrak dengan pelarut etanol yang selanjutnya dianalisis aktivitas antioksidannya dengan metode 1,1-difenil-2-pikrilhidrazil (DPPH). Hasil penelitian menunjukkan pertumbuhan optimal terjadi pada salinitas $30 \mathrm{ppt}$, dan aktivitas antioksidan tertinggi dicapai pada salinitas 20 ppt $(9,88 \pm 0,59)$ yang termasuk dalam kategori lemah.
\end{abstract}

Kata kunci: Dunaliella salina; Salinitas; Pertumbuhan; Antioksidan

\section{The effects of salinity on growth and Antioxidant Activity of Microalgae Dunaliella salina (Chlorophyceae: Dunaliellaceae)}

ABSTRACT: Dunaliella salina is a type of green microalgae that contains various bioactive compounds including antioxidant compounds to fight free radicals. Microalgal growth is influenced by the environmental conditions such as salinity. This study aims were to determine the optimal salinity of growth and antioxidant activity in ethanol extract based on percent inhibition values. This research was conducted in the Integrated Laboratory and Biology Laboratory of the Faculty of Fisheries and Marine Sciences, Diponegoro University, Semarang in May - July 2018. The research method used was an experimental laboratory. $D$. salina was cultivated with five different salinities on 20, 25, 30, 35 and $40 \%$. Observation was carried out for $7 \times 24$ hours, harvested and extracted with ethanol solvent and then analyzed its antioxidant activity by 1,1-diphenyl-2-picrylhydrazyl (DPPH) method. The results showed that optimal growth of $D$. salina was $30 \%$ in salinity, and the highest antioxidant activity was $20 \%$ in salinity $(9.88 \pm 0.59)$ and included in the weak category.

Keywords: Dunaliella salina; Salinity; Growth; Antioxidant activity

\section{PENDAHULUAN}

Mikroalgae berpotensi dalam pengembangan bidang farmasi terutama karena berberapa spesies dapat memproduksi senyawa metabolit bersifat bioaktif. Potensi metabolit mikroalgae kini mulai dikembangkan peneliti khususnya dalam hubungan Reactive Oxidative Species (ROS) atau dikenal sebagai radikal bebas (Borowitzka, 2013). ROS merupakan faktor penuaan dan patogenesis berberapa penyakit degeneratif. Perubahan dan kerusakan jaringan organ dalam disebabkan gangguan transkripsi DNA/RNA sehingga reaksi intraseluler menyebabkan inaktifasi sel yang berakibat mengubah struktur intraseluler yang memperburuk sistem fisiologis organisme yang dapat menyebabkan kematian sel. Gangguan tersebut terjadi melalui reaksi peroksidasi lemak antara ROS dengan asam lemak tak jenuh dalam biomembran, yang menyebabkan desaturasi sehingga menghambat transkripsi DNA/RNA. 
D. salina merupakan jenis mikroalgae dari keluarga Chlorophyceae. Faktor lingkungan yang mempengaruhi produksi senyawa metabolit adalah: salinitas tinggi, intensitas cahaya tinggi, dan keterbatasan nitrogen. Dalam kondisi salinitas tinggi, dapat ditemukan $\beta$ - karoten hingga 10\% dari total berat kering. $D$. salina dalam kondisi optimal dapat menghasilkan $\sim 400 \mathrm{mg} \beta-\mathrm{karoten} / \mathrm{m}^{2}$ (Finney et al., 1984).

Salinitas dianggap mempengaruhi karena mengakibatkan adanya tekanan osmosis melalui pertukaran ion (Djunaedi et al., 2017). Tekanan osmosis ini juga memicu perubahan protein menjadi asam piruvat yang digunakan sebagai bahan dasar pembentukan lutein (Imron et al., 2016). Penelitian ini bertujuan untuk mengetahui pengaruh salinitas terhadap pertumbuhan dan aktivitas antioksidan $D$. salina, Hasil dari penelitian ini diharapkan dapat menjadi sumber informasi mengenai salinitas terbaik untuk pertumbuhan sel dan aktivitas antioksidan pada $D$. salina dan menjadi penunjang referensi dalam produksi antioksidan industri farmakologi.

\section{MATERI DAN METODE}

Materi yang digunakan adalah D.salina. Media pertumbuhan disterilisasi dengan autoklaf pada temperatur $121^{\circ} \mathrm{C}$ pada tekanan $1 \mathrm{~atm}$ selama 20 menit. Alat yang digunakan disterilisasi dengan menggunakan lampu UV 20 watt selama 2 jam dan alkohol 70\%. Larutan stock steril dengan salinitas 40 ppt diencerkan menjadi salinitas 20, 25, 30, 35, dan 40 ppt. Pengukuran salinitas menggunakan rumus (Rahma et al.,2014). Kultivasi Zainuddin et al. (2017) dengan perbandingan 1:2 ( D. salina : air laut steril) dan ditambahkan pupuk Walne sebanyak $1,5 \mathrm{~mL}$ ke dalam kultiva (dosis $1 \mathrm{~mL} / \mathrm{L}$ ). Pengamatan setiap 24 jam selanjutnya sebanyak $2 \mathrm{~mL}$ dimasukan ke dalam botol vial, selanjutnya dihitung dengan sedgewick rafter.

Pemanenan biomassa dengan cara mengambil $5 \mathrm{~mL}$ sampel dan dimasukan ke dalam botol vial yang dibungkus dengan aluminium foil dan disentrifuge pada kecepatan $3000 \mathrm{rpm}$ selama 5 menit (Imron et al., 2016). Supernatan dibuang dan endapan yang terbentuk ditimbang menggunakan timbangan analitik sehingga didapatkan berat biomassa basah.

Ekstraksi dilakukan dengan melakukan maserasi biomassa basah dengan pelarut ethanol selama 3x24 jam dengan perbandingan 1:10 (gram biomassa basah : mililiter pelarut ethanol), sampel disonifikasi selama 15 menit pada gelombang $50 \mathrm{kHz}$ pada suhu ruang dan disaring. Hasil filtrat yang terbentuk dievaporasi dengan rotatory evaporator pada suhu $39^{\circ} \mathrm{C}$. Pengukuran absorbansi dengan menggunakan spektrofotometer pada panjang gelombang $517 \mathrm{~nm}$. Persen penghambatan atau aktivitas antioksidan dihitung menggunakan persamaan (Sanchez et al., 1998).

\section{HASIL DAN PEMBAHASAN}

Hasil analisis pengaruh salinitas terhadap pertumbuhan $D$. salina dapat dilihat pada Gambar 1. Dari gambar tersebut dapat dilihat bahwa kepadatan sel tertinggi $D$. salina pada semua perlakuan dicapai pada hari ke-3 perlakuan C $(30 \%)$, sehingga salinitas $30 \%$ merupakan media tumbuh yang optimum. Hasil analisa statistik menunjukkan bahwa hanya perlakuan salinitas 30 $\%$ menunjukkan beda nyata dengan perlakuan salinitas $40 \%$. Sedangkan perlakuan salinitas 20, 25, 35 dan $4040 \%$ tidak menunjukkan beda nyata (Tabel 1).

Kepadatan sel terendah pada salinitas tinggi perlakuan $40 \%$, menunjukkan penurunan pertumbuhan, yang diduga penurunan kinerja fotosintesis disebabkan oleh klorofil yang terdisintegrasi akibat ion $\mathrm{Na}+$ yang berlebih (Ashraf \& Harris, 2013). Singh \& Kashtriya (2002) salinitas tinggi membuat lingkungan sekitar sel menjadi lebih pekat dari keadaan normal sehingga sel cenderung menarik ion dan sel kekurangan air menyebabkan kandungan klorofil dalam mikroalga berkurang untuk menyeimbangkan keadaan cairan di dalam sel. Kebeish et al. (2014) salinitas tinggi mengakibatkan sel memiliki ion berlebih yang bersifat toksik. Hasil ini sesuai dengan hasil penelitian yang dilakukan Zainuddin et al. (2017) bahwa kepadatan sel tertinggi dicapai oleh $D$. salina pada salinitas $30 \%$. Hal ini disebabkan karena pengaruh lingkungan media pemeliharaan, seperti suhu, tingkat keasaman media $(\mathrm{pH})$, dan salinitas (Masithah et al., 2011). Salinitas berpengaruh terhadap pertumbuhan, karena salinitas berbeda pada setiap perlakuan berpengaruh terhadap tekanan osmotik. Bentuk adaptasi lingkungan yang dilakukan pada salinitas tinggi adalah membentuk zat organik aktif secara osmotik pada sel, menyebabkan konversi 
glukosa menjadi gliserol melalui proses glikolisis atau pemecahan gula sehingga glukosa dapat dipakai secara optimum untuk pertumbuhan sel ( Jaeger et al., 2018).

D. salina dilindungi membrane plasma tipis (periplast), memungkinkan terjadinya perubahan bentuk, ukuran dan biomassa sel dengan cepat (Venkatsan et al., 2013). Peningkatan kadar garam dalam lingkungan media pertumbuhan mempengaruhi turunnya laju fotosintesis, karena salinitas tinggi mengganggu pertumbuhan $D$. salina berupa perubahan rasio ionik akibat permeabilitas membran dan tekanan ion (Mata et al., 2010). Salinitas tinggi, menyebabkan konsentrasi ion eksternal meningkat. Untuk mencapai kesetimbangan, ion akan memasuki sel dan air akan meninggalkan sel. Pada kasus yang parah, membrane sel, organel intraseluler, dan enzim akan rusak. Sedangkan pada salinitas menurun, untuk mencapai keseimbangan ion, air akan masuk dalam sel untuk mengurangi konsentrasi ion, jika air masuk terlalu banyak sel akan rusak (Lobban \& Harrison 1987).

Hasil analisis statitistika pengaruh salinitas terhadap aktivitas antioksidan dapat dilihat pada Tabel 2. Dari table tersebut terlihat bahwa nilai persen inhibisi tertinggi pada salinitas $20 \%$. Hal ini diduga karena salinitas tinggi mampu menurunkan nilai absorbansi DPPH sejumlah 9,88 \pm 0,597 $\%$ dari absorbansi awal sebelum dicampurkan ekstrak. Hasil ini menunjukan bahwa $D$. salina melakukan proses pembentukan karotenoid (Jupin \& Lamant,1999), yang berperan dalam pertahanan terhadap senyawa-senyawa reaktif yang mengganggu fungsi sel. $D$. salina mengalami tekanan osmotik akibat perbedaan salinitas pada media kultivasi. Salinitas pada media kultivasi berpengaruh terhadap pembentukan karotenoid. Hal ini diduga karena ion $\mathrm{Na}+$ dan $\mathrm{Cl}-$ mengganggu keseimbangan osmotik antar bagian dalam sel dengan lingkungan luar sel (Imron et al., 2016). Ketidakseimbangan ini akan mendorong sel untuk beradaptasi dengan mengeluarkan metabolit sekunder untuk mendukung penyesuaian hidup sel terhadap peningkatan salinitas.

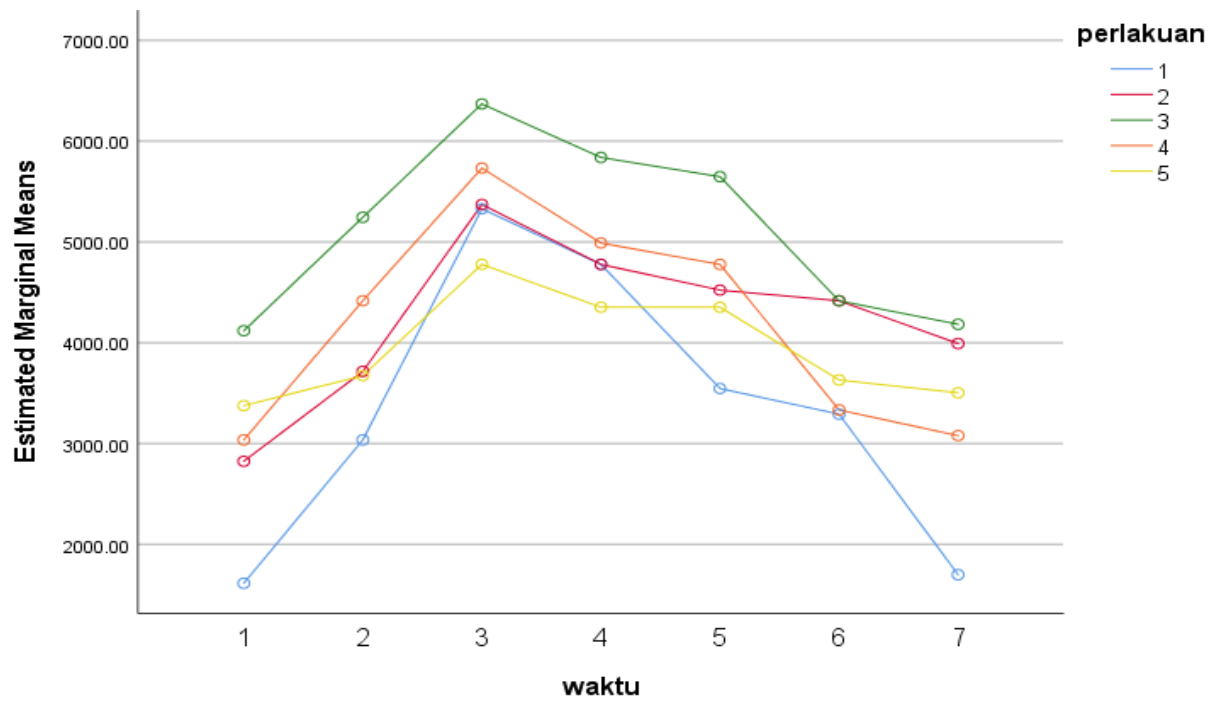

Gambar 1. Grafik Kepadatan D. salina Harian pada Perlakuan Salinitas yang Berbeda (Keterangan $1=20$ ppt, $2=25$ ppt, $3=30$ ppt, $4=35$ ppt, $5=40$ ppt)

Tabel 1. Hasil uji tingkat II BNJ Kepadatan Hari Ketiga D. salina pada Salinitas Berbeda

\begin{tabular}{cl}
\hline Salinitas (\%) & Rerata \pm Sd $(\%)$ \\
\hline 20 & $5329,08 \pm 156,50^{\mathrm{ac}}$ \\
25 & $5371,54 \pm 262,04^{\mathrm{ac}}$ \\
30 & $6369,42 \pm 441,97^{\mathrm{ab}}$ \\
35 & $5732,48 \pm 122,57^{\mathrm{ac}}$ \\
40 & $4777,07 \pm 122,58^{\mathrm{c}}$ \\
\hline
\end{tabular}

Keterangan: simbol huruf yang berbeda menunjukkan signifikansi perlakuan 
Tabel 2. Hasil uji tingkat II BNJ antioksidan spesifik alga $D$. salina pada salinitas berbeda

\begin{tabular}{cl}
\hline Salinitas (\%) & Rerata \pm Sd (\%) \\
\hline 20 & $9,88 \pm 0,59^{\mathrm{a}}$ \\
25 & $8,86 \pm 0,12^{\mathrm{ab}}$ \\
30 & $7,35 \pm 1,31^{\mathrm{bc}}$ \\
35 & $8,27 \pm 0,47^{\mathrm{ab}}$ \\
40 & $6,33 \pm 0,60^{\mathrm{c}}$ \\
\hline
\end{tabular}

Keterangan: simbol huruf yang berbeda menunjukkan signifikansi perlakuan

\section{KESIMPULAN}

Dari hasil penelitian ini dapat disimpulkan bahwa salinitas berpengaruh terhadap pertumbuhan dan aktivitas antioksidan $D$. salina. Pertumbuhan optimal $D$. salina dicapai pada perlakuan salinitas $30 \%$. Sedangkan aktivitas antioksidan tertinggi dicapai pada perlakuan salinitas $20 \%$. Nilai aktivitas ini termasuk dalam kategori lemah.

\section{DAFTAR PUSTAKA}

Ashraf, M. \& Harris, P.J.C. 2013. Photosynthesis Under Stressful Enviroments: An Overvie. Photosyntetica, 51(2):163-190. doi: 10.1007/s11099-013-0021-6

Borowitzka, M.A. \& Moheimani, N.R. 2013. Algae for Biofuel and Energy. Springer. New York. Pp. 17-28.

De Jaeger, L., Carreres, B.M., Springer, J., Schaap, P.J., Eggink, G., Dos Santos, V.A.M., Wijffels, R.H. \& Martens, D.E. 2018. Neochloris oleoabundans is worth its salt: Transcriptomic analysis under salt and nitrogen stress. PloS one, 13(4):0194834. doi: 10.1371/journal.pone.0194834

Djamil, R. \& Anelia, T., 2009, Penapisan Fitokimia, Uji BSLT, dan Uji Antioksidan, Jurnal IImu Kefarmasian Indonesia, 7(2):65-71.

Djunaedi, A., Chrisna, A.S. \& Sardjito. 2017. Kandungan Pigmen Polar dan Biomassa pada Mikroalga Dunaliela salina dengan Salinitas yang Berbeda. Jurnal Kelautan Tropis, 20(1):1-6. doi: 10.14710/jkt.v20i1.1347

Imron, M.A., Sudarno \& Mastihah, E.D. 2016. Pengaruh Salinitas Terhadap Kandungan Lutein pada Mikroalga Botryococcus braunii. Journal Marine and Coastal Science, 5(1):36-48.

Jupin, H., \& Lamant. A. 1999. La Photosynthese. Dunod. French

Kebeish, R., El-Ayouty, Y. \& Hussein, A. 2014. Effect of Salinity on Biochemical Traits and Photosynthesis-Related Gene Transcription in Chlorella vulgaris. Egypt Journal Botany, 54(2):281-294. doi: 10.21608/ejbo.2014.492

Lobban, C.S., \& Harrison, P.J. 1987. Seaweed Ecology and Physiology. Cambridge University Press

Masithah, E.D., Ariesma, N., \& Cahyon, Y. 2011. Pengaruh Pemberian Bakteri Bacillus pumilus Pada Rumen Sapi Sebagai Pupuk Terhadap Pertumbuhan Dunaliela salina. Jurnal Kelautan, 4(1): 82-89.

Mata, T.M., Martins, A.A., \& Caetano, N.S. 2010. Microalgae for biodiesel production and othe application: A review. Renewable and Sustainable Energy Reviews, 14: 217-232. doi: 10.1016/j.rser.2009.07.020

Rahma, H.N., Prayitno, S.B. \& Haditomo, A.H.C., 2014. Infeksi white spot syndrom virus (WSSV) pada udang windu (Penaeus monodon fabr.) yang dipelihara pada salinitas media yang berbeda. Journal of Aquaculture Management and Technology, 3(3):26-34.

Sanchez, C., Laurrauri, J.A., \& Saura, F. 1998. A Procedure To Measure The Antiradical Efficiency of Polyphenols. Journal of The Science of Food and Agriculture, 76(2),270-276. doi: 10.1002 /(SICI)1097-0010(199802)76:2<270::AID-JSFA945>3.0.CO;2-9. 
Singh, D.P. \& Kashtriya, K. 2002. NaCl-induced Oxidative Damage in The Cyanobacterium Anobena doliolum. Journal Microbiology. 44:411-417.

Venkatsen, S., Swamy M.S., Senthil, C., Bhaskar, S \& Rengasamy, R. 2013. Culturing Marine Green Microalgae Dunaliella salina Teod. And Dunaliella tertiolecta Masjuk in Dewalne's Medium for Valuable Feeds Stock. Journal of Modern Biotechnology. 2(2):40-45.

Zainuddin, M., Hamid, N., Murdiarti, L., Kursistyanto, N., \& Aryono, B. 2017. Pengaruh Media Hiposalin dan Hipersalin Terhadap Respon Pertumbuhan dan Biopigmen Dunaliella salina. Jurnal Enggano, 2(1):46-57. 